Portland State University

PDXScholar

$12-2021$

\title{
How Has Cultural Marxism Been Used as a Political Tactic in Order to Decrease Trust in Higher Education?
}

Drew Havnaer

Portland State University

Follow this and additional works at: https://pdxscholar.library.pdx.edu/honorstheses

Part of the American Politics Commons, Other Political Science Commons, and the Political Theory Commons

Let us know how access to this document benefits you.

\section{Recommended Citation}

Havnaer, Drew, "How Has Cultural Marxism Been Used as a Political Tactic in Order to Decrease Trust in Higher Education?" (2021). University Honors Theses. Paper 1161.

https://doi.org/10.15760/honors.1182

This Thesis is brought to you for free and open access. It has been accepted for inclusion in University Honors Theses by an authorized administrator of PDXScholar. Please contact us if we can make this document more accessible: pdxscholar@pdx.edu. 
How has Cultural Marxism been used as a Political Tactic in Order to Decrease Trust in Higher Education?

\author{
by \\ Drew Havnaer \\ An undergraduate honors thesis submitted in partial fulfillment of the \\ requirements for the degree of \\ Bachelor of Arts \\ in \\ University Honors \\ and \\ Political Science
}

Thesis Adviser

Jack Miller, Ph. D

Portland State University

2021 


\begin{abstract}
This thesis will address the rise in popularity of the political notion of the 'Culture War.' It will trace this theory from its origins in the mid-20th century, through the landmark 1992 Buchanan Culture War speech, and to a modern version, often referred to as the theory of Cultural Marxism. The first part of the argument identifies employment of this theory by modern conservatives, and analyzes how many of us encounter it in our daily life, most prominently in reference to higher education. The second part of the argument targets the effect in colleges and universities specifically. It identifies how these ideas are introduced to college students and what purpose they serve.
\end{abstract}

Keywords: Culture War, Cultural Marxism, Liberal, Conservative, Education 


\section{Background}

In the late 1980s, as the Cold War drew to a close, and the Soviet menace began to fade from the minds of Americans, a new conflict arose. The better part of a generation had been subject to a constant power struggle between two superpowers: the United States and the Soviet Union. As this conflict faded from view, more or less the result of an American victory, many U.S. conservatives began to lean on a new conflict in order to motivate their voting blocks. For years, these politicians had relied on the fear of communism and accusations of socialists within the United States to keep their voters engaged; see for example the McCarthy trials. However, this new theory, that of the enduring Culture War within the borders of the United States, usurped the fear of communism as the USSR dissolved.

Simply put, the Culture War signifies “debates concerning the wide range of social institutions [amounting] to a struggle over the meaning of America" (Hunter \& Wolfe, 2006). As defined by Pat Buchanan, one of the largest proponents of this theory: "There is a religious war going on in this country... as critical to the kind of nation we shall be as the Cold War itself. For this war is for the soul of America" (Buchanan, 1992). This definition was delivered by Buchanan at the 1992 Republican National Convention as he threw his support behind former rival George H. W. Bush who was running for reelection. Known as the Culture War Speech, this allocation was arguably the catalyst which propelled the theory into the general consciousness. However, Buchanan's address is by no means the genesis of this theory. 
Although the origins of this theory are somewhat murky, many scholars point to William F. Buckley Jr.'s God and Man at Yale: The Superstitions of 'Academic Freedom' as one of the foundational texts of the Culture War Theory. Buckley's 1951 book argues that many of the staff at Yale, a supposedly religious institution, in fact carry bias against religion and conservative values and are, deliberately or inadvertently, passing on that bias to their students. Not only is Buckley's book critical to the development of the broader theory of a cultural war, but it also directly addresses the topic of this thesis, higher education and the theory of Cultural Marxism.

This thesis will address Cultural Marxism as a distinct subsect of the Culture War Theory. While that theory describes a broad conflict between conservative and liberal ideology, Cultural Marxism borders increasingly on conspiracy. Cultural Marxism argues that intellectuals have "infiltrated America through the minds of its youth" and that "while the West was busy winning the Cold War abroad, it had in fact unknowingly ceded ground to Cultural Marxism at home, particularly through higher education" (Tuters 2018). Broadly, Cultural Marxism is the theory that the elites have conspired to indoctrinate future generations into the fold of socialism or liberalism through institutional structures. 


\section{Discourse}

The scholarly community surrounding Cultural Marxism encompasses the disciplines of history, political science, and philosophy, and occupies the shared study of political theory or political philosophy. Much of the work seeks to understand Cultural Marxism, and the Culture War by extension. Articles like those of Marc Tuters or of Busbridge, Moffitt, and Thorburn attempt to categorize the theory and to understand why it has taken hold so firmly in western society. Others, such as Hunter and Wolfe's Is There a Culture War? interrogate the validity of the theory itself, discussing whether there is indeed a culture war. This thesis will fill a hole in the discourse by providing a look at the targeted attempts made by proponents of the theory designed to influence college aged individuals. Additionally, the thesis will combine other social science work to determine whether the ongoing attempts to sew distrust have been successful. 


\section{Culture War vs Cultural Marxism}

The key difference to note between the two large topics of this thesis, Culture War and Cultural Marxism, is simply their levels of mass appeal. While Cultural Marxism exists as a subsect of the belief in a culture war, it is far more fringe than its parent. The belief in Cultural Marxism is almost exclusively a conservative one. On the other hand, the belief that Conservative and Liberal values are at odds with each other, bordering on war, is one that many on the left subscribe to as well. This can be seen very plainly in the parallels between Buchanan's assertion that “this war is for the soul of America" (1992) and Joe Biden's 2020 campaign slogan "battle for the soul of the nation."

The theory of Cultural Marxism relies heavily on the assertion that politicians, educators, and elites conspire in order to alter the opinions of the populace, often young americans. While the Culture War is all encompassing; it stretches into most facets of American society, Cultural Marxism targets the minds of the next generation. For this reason we see accusations against educators frequently within this framework. This circle within a circle definition can somewhat muddy the waters between the two ideas but what is vital to understand is that accusations of brainwashing future generations can largely be attributed to the theory of Cultural Marxism. 


\section{Deployment of the Theory}

Although Cultural Marxism theory still centers around the same principles, the way that its information is disseminated has changed significantly in the years since Buckley. In particular, the internet has widened the spread of the theory and allowed it to become somewhat mainstream. One chief contributor to this reanimation of Buckley's ideas is Prager University. Prager University, or PragerU for short, is a 501(c)(3) public charity based in Sherman Oaks, California. The organization is headed by talk radio host and conservative activist Dennis Prager. If one takes a look at PragerU's website or Youtube Channel, it is clear that their primary method of dissemination is through short form videos. These videos feature some of the internet's most popular conservative pundits, including Candace Owens, Ben Shapiro, Jordan Peterson, Will Witt, Charlie Kirk, and often Prager himself. Most of this content is targeted towards adolescents, likely in highschool or college. However, they also run several programs with the goal of reaching younger audiences. A simple search for the word 'College' on PragerU's website will turn up a plethora of videos which argue that college is either not worth the investment or that it is inherently biased against conservative students. With videos like "Is College Worth It?" featuring Charlie Kirk, or "Does College = Success?" which posits that since successful men such as Bill Gates and Mark Zuckerberg dropped out of university, it is not necessary for success. Prager University also produces a series called 'Man on the Street' with host Will Witt. The program features Witt performing a traditional man on the street routine, which the title suggests, with a significant conservative bent. Most episodes are punctuated by Witt asking often biased questions to students on college campuses, most of whom identify as something near liberal, in order to demonstrate that their ideology is somehow contradictory, convoluted, or that the students are unintelligent for not being able to back up their opinions on 
the spot. This series is meant to not only bolster Prager University's political agenda, but it also serves to demonstrate how liberal and biased college campuses are, at least according to Dennis Prager.

The conservative media outlet Turning Point USA is one of the largest modern proponents of the Cultural Marxism Theory. The organization was also founded by frequent Prager University Contributor Charlie Kirk. While PragerU broadly promotes conservative and culture war content aimed at young adults, Turning Point USA is highly oriented towards a distrust in higher education. The organization creates targeted media content and provides services for conservative groups on college campuses, such as keynote speakers. Perhaps one of the most obvious examples of Turning Point's propagation of the theory is a link on their website titled "Professor Watchlist." The Professor Watchlist allows potential students to research professors which could harbor biases against conservatives. Additionally, the site is adorned with banners reading "Support our Fight" which lead viewers to a donation page. This type of language is by no means new and it mirrors the views of William F Buckley Jr. a half century prior.

Turning Point USA is also widely known on the internet for its use of memes to connect with college aged people. Below are three examples of these memes making various arguments associated with the theory of Cultural Marxism. Short form media such as memes have become a large part of the tactics used to decrease trust in colleges and universities. 


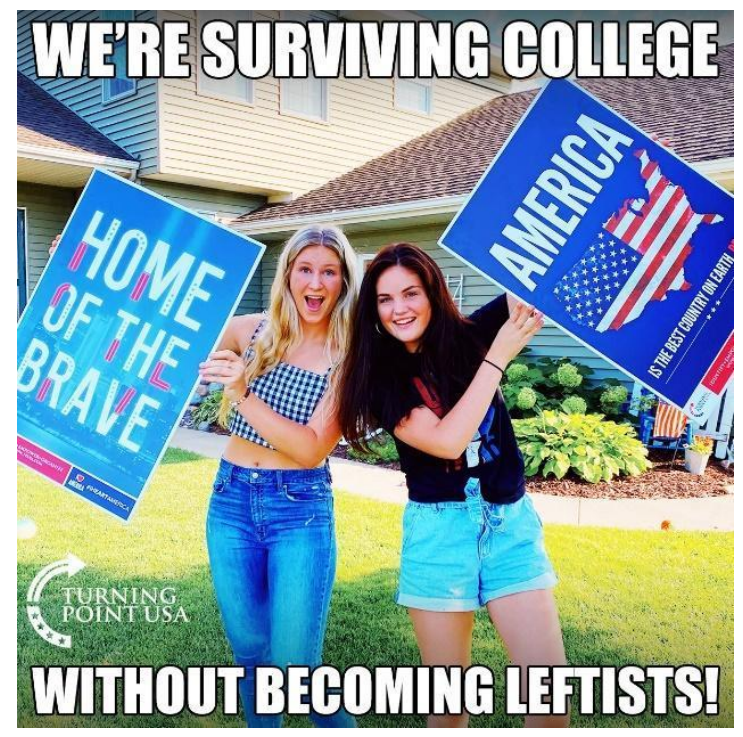

Figure 2. Propagating the central ideas behind cultural Marxism, that elites and liberals control major institutions
Figure 1. Arguing that becoming liberal and attending a university are inherently linked

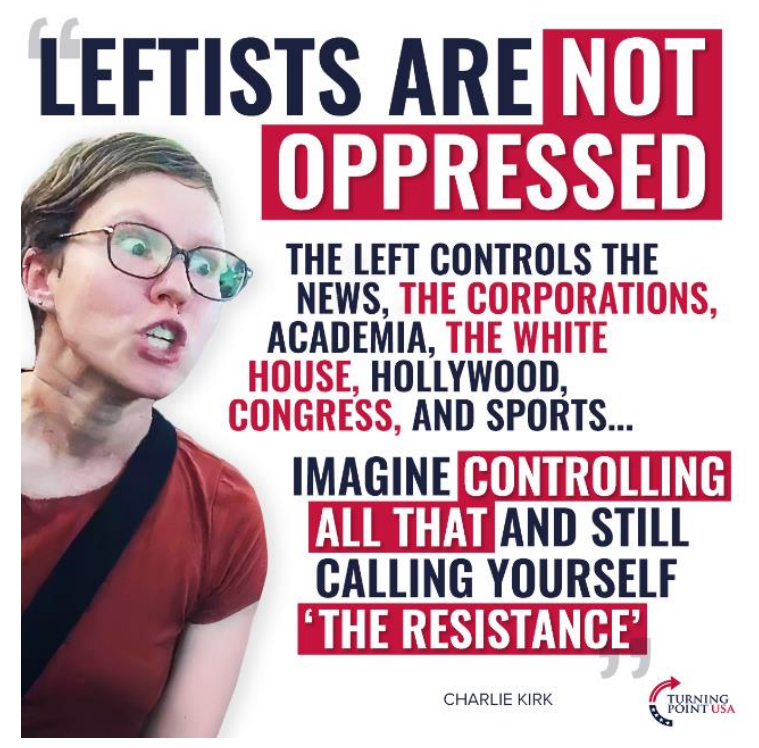

\section{WHAT THEY WON'T TELL YOU IN SCHOOL..}

NOBODY NEEDS TO ATTEND AN EXPENSIVE UNIVERSITY TO FIND SUCCESS IN LIFE

ALL IT TAKES IS A GOOD WORK ETHIC AND A DESIRE TO IMPROVE YOUR OWN SITUATION

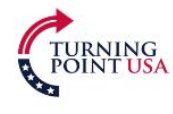

Figure 3. Discouraging young people from attending a university 


\section{The Attempt to Influence}

The main question of this article is, why go to all this trouble attempting to change adolescent's opinions about attending a University? Surprisingly, it is not for the reasons that right wing pundits claim. While outlets like Prager University and Turning Point USA argue that Universities are places where youth are indoctrinated into the liberal ideology, this is actually not the case. According to research published in The Conversation, a news publication for in depth, peer reviewed journalism, first and second year college students do not change their beliefs much at all. The reality is that being in a university setting exposes them to new viewpoints, which they gain an understanding for. After one year of college $47.8 \%$ of students surveyed reported having better opinions of liberals and $49.6 \%$ towards conservatives.

The real reason behind the use of Cultural Marxism theory has more to do with demographics than anything else. While Americans as a whole are still relatively evenly divided on social issues and actually lean more conservatively on economic issues (Gallup) young Americans are a different story altogether. According to the Center for Information and Research on Civic Learning and Engagement (CIRCLE) of Tisch College at Tufts University, of the roughly 24 million youth who turned out to vote in the 2016 election "young voters supported Hillary Clinton over Donald Trump by 55\% to 37\%." Additionally, the Pew Research Center identifies a generational gap in America's political leanings. Millennials are evidently becoming increasingly liberal. One piece of evidence which Pew sites is the difference in approval ratings for former presidents Trump and Obama, especially among. Overall, millennials had a notably higher opinion of Obama and notably lower opinion of Trump than any other generation. 
This is what the descendants of Buckley understand that many Americans are not aware of. We may not be swaying the entire country towards the left, but we are swaying younger generations. It won't be long until the millennial generation is one of the older groups and if the trend holds, more of the electorate will favor the left. The work of PragerU and TPUSA is preemptive. They are attempting to prevent the shift towards the left amongst young people. Even though many students do not change their beliefs significantly at university, perhaps Dennis Prager and Charlie Kirk can change that. 


\section{Works Cited}

Buchanan, P. (1992, August 17). Culture War Speech: Address to the Republican Convention.

Buckley, W. (1951). God and man at Yale; the superstitions of academic freedom.

Does College $=$ Success. (2020, August 3). Prager University.

Election Night 2016: 24 Million Youth Voted, Most Rejected Trump. (2016). Tisch College Center for Information and Research on Civic Learning and Engagement.

Hunter, J. D. (2006). Is there a culture war? : A dialogue on values and American public life.

Is College Worth It? (2019, August 26). Prager University.

Is Free College a Good Idea. (2021, March 10). Prager University.

Mayhew, M., Rockenbach, A., Selznick, B., \& Zagorsky, J. (2018, February 2). Does College Turn People Into Liberals? The Conversation.

Moffitt, B., \& Thorburn, J. (2020). Cultural Marxism: Far-right conspiracy theory in Australia's culture wars. Social Identities: Journal for the Study of Race, Nation, and Culture.

Saad, L. (2021). Americans More Divided on Social Than Economic Issues. Gallup.

The Generation Gap in American Politics. (2018). Pew Research Center.

Turning Point USA. (2021a). What They Won't Tell You in School.

Turning Point USA. (2021b). We're Surviving College Without Becoming Leftists! 
Turning Point USA. (2021c). Leftists Are Not Oppressed.

Tuters, M. (2018). Cultural Marxism. Krisis: Journal for Contemporary Philosophy. 